\title{
Migdolus fryanus Damage Causes Decrease in the Starch Content in Manihot esculenta
}

\author{
Júlio C. Guerreiro ${ }^{1}$, Ana P. Azevedo ${ }^{1}$, Renan R. Espessato ${ }^{1}$, Vanda Pietrowski ${ }^{2}$, Rudiney Ringenberg ${ }^{3}$, \\ Pedro J. Ferreira Filho ${ }^{4}$, Rerison C. da Hora ${ }^{1}$, Evandro P. Prado ${ }^{5} \&$ Thaise M. Pascutti ${ }^{1}$ \\ ${ }^{1}$ Departamento de Ciências Agronômicas, Universidade Estadual de Maringá, Campus de Umuarama, Bairro \\ São Cristóvão, Umuarama, Paraná, Brazil \\ ${ }^{2}$ Centro de Ciências Agrárias, Universidade Estadual do Oeste do Paraná, Campus Marechal Cândido Rondon, \\ Paraná, Brazil \\ ${ }^{3}$ Centro Nacional de Pesquisa de Mandioca e Fruticultura, Cruz das Almas, Bahia, Brazil \\ ${ }^{4}$ Departamento de Ciências Ambientais, Universidade Federal de São Carlos, Campus Sorocaba, Sorocaba, São \\ Paulo, Brazil \\ 5 Faculdade de Ciências Agrárias e Tecnológicas, Universidade Estadual Paulista "Júlio de Mesquita Filho", \\ Dracena, São Paulo, Brazil \\ Correspondence: Júlio C. Guerreiro, Departamento de Ciências Agronômicas, Universidade Estadual de Maringá, \\ Campus de Umuarama, Estrada da Paca s/n, CEP: 87500-000, Bairro São Cristóvão, Umuarama, Paraná, Brazil. \\ E-mail: jcguerreiro@uem.br
}

Received: April 30, 2019

doi:10.5539/jas.v11n15p97
Accepted: July 20, 2019 Online Published: September 15, 2019

URL: https://doi.org/10.5539/jas.v11n15p97

\begin{abstract}
The beetle M. fryanus causes serious damage to cassava in Brazil. However, due to the subterranean behavior of the larvae and the recent appearance of this pest in cassava, little is known about the main behavioral characteristics and damage caused to this crop. The main aim of this study is to demonstrate the variation of starch production in the roots of $M$. esculenta as a result of the intensity of damage caused by M. fryanus. The study was carried out in a commercial cassava farm in Paraná, Brazil. The proposed scale for damage was: (1) No apparent root damage; (2) roots with scrapings; (3) roots with scraping across the cortex; (4) damaged roots and galleries; (5) roots with galleries and presentation of rot. The parameters evaluated were the damage caused by M. fryanus in roots and starch content, estimated by using a hydrostatic scale, starch extracted by cassava processing, and the starch reduction percentage in damaged roots, assessed by using the hydrostatic scale (SC) and processing methods (SCP). It was observed that there was manifestation of damage in approximately $60 \%$ of the roots collected directly from the ground, with levels representing loss of starch produced by the plant. Decreases in the productive parameters, such as starch content, were measured according to the increase of the proposed damage levels in the two cassava cultivation cycles, with a starch reduction rate higher than $20 \%$ when the roots suffered the most severe damage.
\end{abstract}

Keywords: root-feeding beetle, drill roots, cassava, soil-borne pest, long-horned beetle

\section{Introduction}

Manihot esculenta Crantz (Malpighiales: Euphorbiaceae) is an important source of calories in the Neotropical region, and because it is rich in carbohydrates, this plant is used for human and animal consumption through "in natura" consumption or through industrial processing. The main products of this plant are flour and starch (FAO, 2008). It is a perennial plant, but its roots can be marketed from six- to twenty-four months after planting. The high amplitude in the harvest period evidences positive aspects, such as, the possibility of market evaluation before harvest, and negative, such as, greater period of plant exposure to pests and diseases (Sagrilo et al., 2006).

Among the pests damaging the cassava crop, the following stand out: Erinnyis ello (L.) (Lepidoptera: Sphingidae), Bemisia tuberculata (Bondar) e Aleurothrixus aepim (Goeldi) (Hemiptera: Aleyrodidae), Phenacoccus herreni Cox \& Williams e Pseudococcus mandio Williams (Hemiptera: Pseudococcidae), Vatiga spp. (Hemiptera: Tingidae), and recently Migdolus fryanus Westwood (Coleoptera: Vesperidae) (Bellotti, Smith, \& Lapointe, 1999; Bellotti, Campo, \& Hyman 2012). 
Larvae of M. fryanus compromise the root system of Eucalyptus, Pinus, grapevine, mulberry, cotton, beans, coffee, pasturage, sugarcane, and cassava plants. However, the main studies and quantification of damage was performed only for sugarcane, with observed reduction in production, of up to $25 \%$ (Machado, Habib, Leite, \& Mendes, 2006; Machado, Habib, Leite, \& Carregari, 2006; Wilcken, Orlato, \& Ottati, 2005; Ugwu \& Ojo, 2015).

M. fryanus is native to South America, with prominent occurrence seen in the sandy soil regions. The larval period of this beetle is extended with subterranean habitat, so studies on the behavior and determination of damage to host cultures are incipient (Bellotti, Campo, \& Hyman 2012; Nakayama et al., 2017).

The $M$. fryanus beetle has caused serious damage to the cultivation of cassava in the Northwest of the State of Paraná, a region that is part of the Arenito Caiuá formation, which has basic sandy soils with an advanced degree of physical and chemical degradation and critical levels of organic matter, especially in pastures and areas of sugarcane reforestation (Machado, Habib, Leite, \& Mendes, 2006; Machado \& Habib, 2006; Pietrowski et al., 2010).

In the cassava, M. fryanus larvae can cause failure in the development of the plant by feeding on its stem cuttings. They can cause loss of starch during production due to damage that may be caused early in the cortex sweeps to the opening in the gallery roots, causing soil deposition and allowing entry of the opportunistic pathogens that predispose it to the occurrence of rot (Machado, Habib, Leite, \& Carregari, 2006; Bellotti, Campo, \& Hyman 2012).

Faced with increased attacks on plants by $M$. fryanus and lack of information about the damage and loss it causes in cassava plants, conducting a research to elucidate its consumption habits and the injuries it causes in this culture is essential (Bellotti, Campo, \& Hyman, 2012; Pietrowski et al., 2010).

The aim of this study is to demonstrate the variation in starch production in M. esculenta roots due to the intensity of damage caused by M. fryanus.

\section{Method}

\subsection{Place of Study}

The study was conducted in Cascata Farm in a commercial plantation of cassava M. esculenta, variety IAC-90, located in the northwest region of Parana in Perobal, PR, Brazil (23 ${ }^{\circ} 51^{\prime} 17.57^{\prime \prime}$ South Latitude, 53 20'40.39" West Longitude, and $425 \mathrm{~m}$ average altitude).

Planting was carried out in 2014 and evaluations were conducted during the first and second crop cycles, 12 and 18 months after planting. A conventional planting system was used, with spacing of $1.00 \times 0.60 \mathrm{~m}$, the fertilizer used was $1000 \mathrm{~kg} \mathrm{ha}^{-1}$ of simple superphosphate, covered with $80 \mathrm{~kg} \mathrm{ha}^{-1}$ of potassium chloride.

Under the conditions of the first crop cycle, for the identification of the insects (adult males) and to evaluate the damage caused by the larvae in cassava roots, pitfall traps were installed containing Migdo® pheromone, in 78 evaluation points, with a spacing of $70 \times 30 \mathrm{~m}$ between plants, located along the trajectory of the spatial points, delimited by the software Google Earth ${ }^{\circledR}$ and Quantum GIS 2.8.3®.

A Global Positioning System (GPS) receiver (Datum WGS 84) and Universal Transverse Mercator (UTM) projection system, zone $22 \mathrm{~S}$, were used according to the categorization of the sample grids. Furthermore, at each evaluated point, three random plants were selected and removed from the soil to distinguish the damages caused by the feeding of $M$. fryanus. The collected insects, M. fryanus adults and larvae, were sent to the Laboratory of Chemical Ecology and Insect Behavior, Department of Entomology and Acarology, "Luiz de Queiroz" School of Agriculture - University of São Paulo.

\subsection{Proposed Visual Scale for Scores to Quantify Damage by M. fryanus}

Based on field observations, the scale of notes with damage intensity caused by M. fryanus on cassava roots and its influence on the production of starch in the culture was elaborated using a visual scale (Pietrowski et al., 2010). The notes were established as follows: Note 1: No apparent damage (scraping) at the root; Note 2: Scraping at the root without overcoming the cortex; Note 3: Scraping at the root overlying the cortex, but without galleries; Note 4: Root with galleries; Note 5: Root with galleries and presence of rot (Figures 1 and 2). 


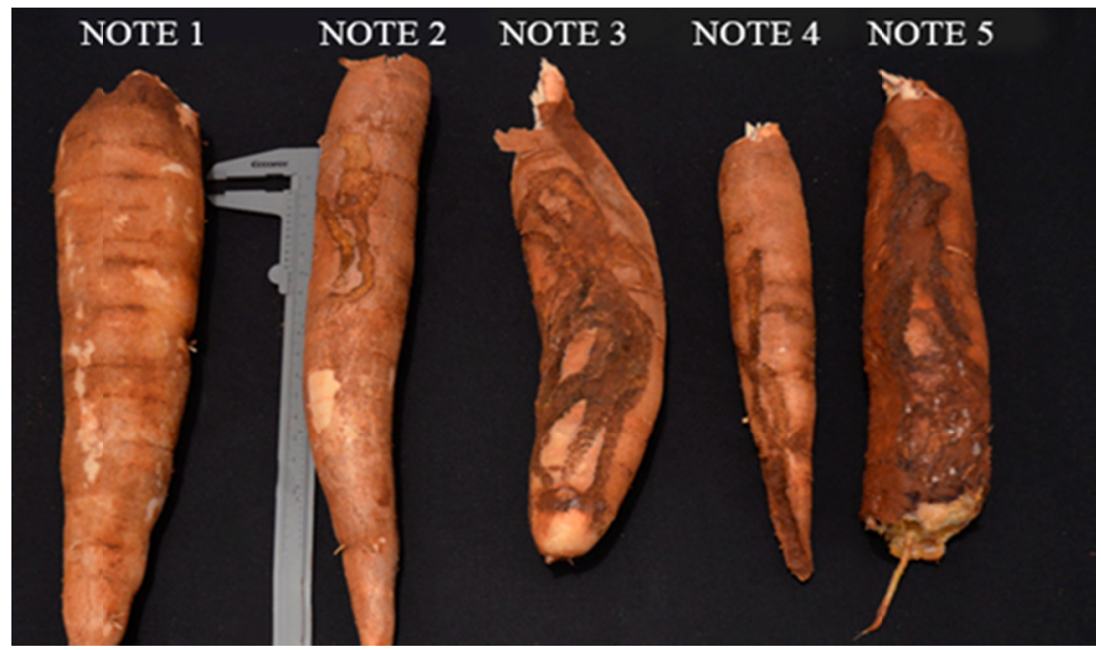

Figura 1. Notes to define scale of M. fryanus damage in M. esculenta. Umuarama, Paraná, 2015 and 2016

\subsection{Starch Production and Influence of M. fryanus Damage}

For the evaluation of starch production of cassava roots in the first and second cropping cycles (harvest at 12 and 18 months after planting), samples of roots that were already extracted from the soil and ready to be sent to the industry were collected. The samples were collected in a targeted manner, according to the damage intensity proposed in this study. The productive parameters of the roots were analyzed in the Laboratory of Entomology of the State University of Maringá, Campus of Umuarama, Paraná.

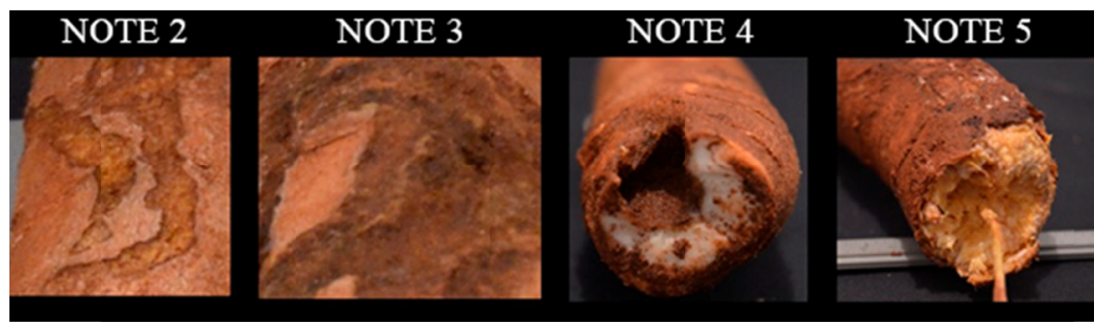

Figura 2. Detail of roots of M. esculenta damaged by larvae of $M$. fryanus according to proposed damage scale. Umuarama, Paraná, 2015 e 2016

\subsection{Starch Content in the Tuberous Roots Using a Hydrostatic Scale}

With the separation of root groups (according to the damage intensity proposed) yield analysis was performed (specific mass of starch) using a hydrostatic scale (SC). To this aim 3-kg root samples were weighed, initially on the upper plate of the scale (mass in the air) and then in a wire basket coupled to the lower part of the same scale, immersed in a water tank (mass in water). This kind of evaluation is standardized by the industry to estimate the starch in cassava roots (Juste Júnior et al., 1983; Maeda \& Dip, 2000).

The estimation of the dry matter and starch content found in the roots was determined after drying at $105{ }^{\circ} \mathrm{C}$. It showed that the dry matter content in the roots increased by an order of $0.0564 \%$ for each unit increase of the sample weight in water. Thus, the following equation was obtained by Sagrilo et al. (2006):

$$
\mathrm{Y}=15.75+0.0564 \mathrm{x}
$$

Where, " $\mathrm{Y}$ " is the dry matter content and " $\mathrm{x}$ " is the specific starch mass of 3-kg roots in water, determined on a hydrostatic scale. The starch content (SC) in the tuberous roots was calculated by subtracting the constant 4.65 dry matter content (Y) (Maeda \& Dip, 2000; Oliveira et al., 2011).

$$
\mathrm{SC}=\mathrm{Y}-4.65
$$

The variation of the starch percentage content in the tuberous roots using a hydrostatic scale (SC), according to the proposed damage scale, was evaluated using a completely randomized design, with 15 replications. The 
scores referent to damage by $M$. fryanus were considered for treatment purposes and evaluated in the first and second crop cycle, totaling to 75 root samples in each harvest cycle.

\subsection{Starch Content Obtained With Cassava Root Processing (SCP)}

Samples $(1 \mathrm{~kg})$ of cassava were processed and separated according to the proposed damage scale. The woody parts at the end, near the stem of the plant, film, and cortex of each sample were removed. Smaller pieces were cut and using an industrial blender with $1000 \mathrm{~mL}$ drinking water, a grinding process was performed (Oliveira et al. 2011). The mixture was filtered through cotton cloth and the crushed mass washed to remove the starch until the liquid showed no whitish color. The liquid obtained from the washing (starch milk) was left in pots protected with a plastic bag for 24 hours, to decant the starch. The supernatant was rejected and the rest of the material submitted to the drying process in a controlled environment until reaching a constant mass. The starch was measured using a semi-analytical scale.

The starch content obtained with cassava root processing (SCP) according to the proposed damage scale was evaluated using a completely randomized design, with 15 replications. The scores referent to damage by $M$. fryanus were considered for treatment and evaluated in the first and second crop cycle, totaling 75 root samples in each harvest cycle.

\subsection{Data Analysis}

Data analysis of damage caused by $M$. fryanus larvae on cassava roots, and the influence of larvae consumption in the estimation of starch content using the hydrostatic scale (SC) and estimation of starch content using the root and residue extraction method (SCP) were performed with normality tests (Shapiro-Wilk) and homogeneity (Levene) and analysis of variance. After verifying the significance, the Tukey test was performed for the quantitative parameters evaluated. The starch reduction percentage was calculated by comparing the starch content in undamaged roots with that in damaged roots. By using the hydrostatic scale (SC) and processing methods (SCP), linear regression analysis for starch content in the root was obtained. Statistical tests were performed with the Agroestat ${ }^{\circledR}$ software (Barbosa \& Maldonado Júnior, 2015).

\section{Results}

Collection of cassava plant roots of the variety IAC 90, directly from the ground was carried out under the conditions of the first cycle (harvest at 12 months after planting). It was possible to confirm the presence of $M$. fryanus and to observe the damage intensities, proposed in this study. In this evaluation we also found larvae of M. fryanus feeding inside the deeper roots containing galleries, as shown in Figure 3.
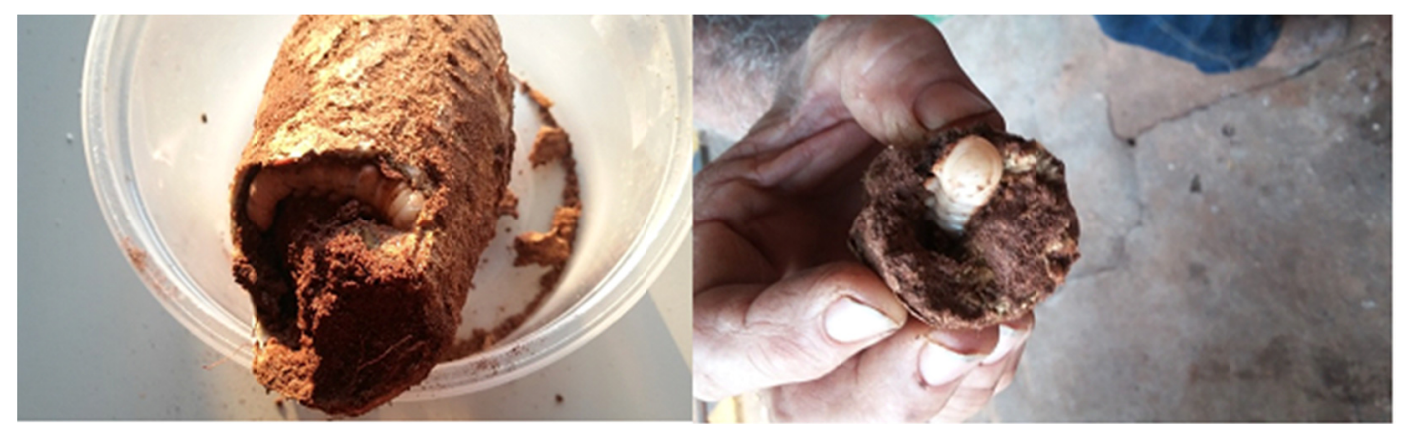

Figure 3. Galleries and Larva of Migdolus fryanus (Coleoptera: Vesperidae) in roots of Manihot esculenta (Euphorbiaceae) variety IAC-90. Umuarama, Paraná, 2016

It was possible to evaluate the occurrence of more than one damaged root in the same plant, with different injuries observed (Figure 4). The total amount of root means observed in each plant (4.32), about $60 \%$ had at least one M. fryanus damage symptom. In addition, in most of the plants, more than $20 \%$ of the roots showed symptoms of damage with a proposed grade above note 4 . This represented the highest losses in starch, roots with galleries, and presence of rot (Tables 1 annd 2, Figures 5 and 6). 


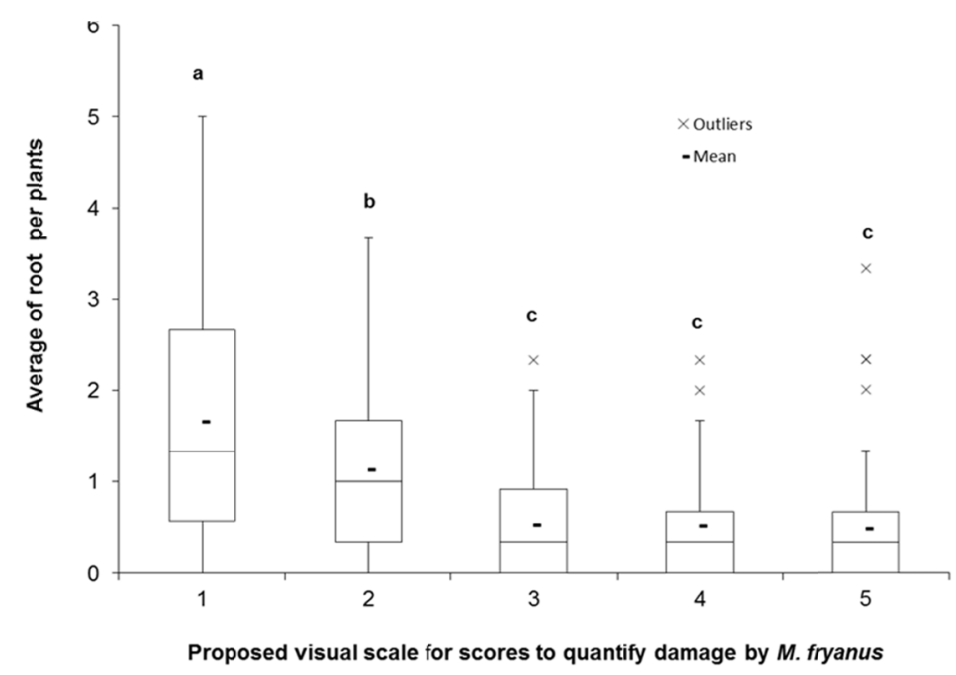

Figure 4. Boxplot showing median, mean, range and interquatile of roots average per plants with their proposed visual scale for scores to quantify damage by M. esculenta. Umuarama, Paraná, 2015 and 2016

The occurrence of roots with symptoms of different damage in the same plant indicates that larvae are walking between the roots and consumption in different roots in the same plant may occur, and in some cases it indicates the presence of more than one insect around the attacked plant.

In the evaluation of productive characteristics directed only to the roots with symptoms of damage, it was noted that the roots collected under the conditions of the first cycle (agricultural year 2015) with damages seen on two, three, four and five levels, had a decrease in starch content when determined on a hydrostatic balance (SC), with a percentage of starch reduction (RSC) alternating from $5.37 \%$ to $21.72 \%$. The roots collected in the second crop cycle (agricultural year of 2016) had a decrease in the starch content that varied from $6.81 \%$ to $23.90 \%$, for damages three, four, and five, when compared with the roots that were not damaged (Table 1).

Table 1. Starch contents obtained with hydrostatic balance (SC \%), percentage of starch reduction with hydrostatic balance (RSC \%). Umuarama, Paraná, 2015 and 2016

\begin{tabular}{llllll}
\hline \multirow{2}{*}{ Damage notes } & \multicolumn{4}{c}{ Cultivation cycles (Year) } \\
\cline { 2 - 3 } \cline { 2 - 3 } \cline { 5 - 6 } & \multicolumn{2}{c}{$1(2015)$} & & \multicolumn{2}{c}{$2(2016)$} \\
\hline 1 & $30.15 \mathrm{a}$ & - & & \\
\cline { 2 - 3 } 2 & $28.53 \mathrm{~b}$ & 5.37 & & $30.71 \mathrm{a}$ & - \\
3 & $27.59 \mathrm{~b}$ & 8.49 & & $28.62 \mathrm{a}$ & 2.25 \\
4 & $25.82 \mathrm{c}$ & 14.36 & & $26.77 \mathrm{c}$ & 6.81 \\
5 & $23.60 \mathrm{~d}$ & 21.72 & & $23.37 \mathrm{~d}$ & 23.90 \\
\hline CV \% & 4.88 & & 4.80 & \\
\hline
\end{tabular}

Note. The averages followed by the same lowercase letter in the column do not differ from each other by the Tukey test applied at the $5 \%$ probability level; CV: coefficient of variation.

The decrease in starch content seen when the evaluation method for extraction processing of cassava (SCP) was used, proved the relation obtained for hydrostatic balance (Tables 1 and 2). The reduction of starch seen by using this method was higher than $20 \%$ in the first cycle of cultivation for the roots that had damage scores 4 and 5 , when compared with those not attacked. In the second crop cycle, the decrease in starch content was less pronounced, with the highest number of roots classified being with damage scores 5 , with a reduction of $28.16 \%$ for this factor. 
Table 2. Starch contents obtained with extraction method with cassava processing (SCP \%), and percentage of starch reduction with cassava processing (RSCP \%) in roots with respective damage notes. Umuarama, Paraná, 2015 and 2016

\begin{tabular}{|c|c|c|c|c|}
\hline \multirow{3}{*}{ Damage notes } & \multicolumn{4}{|c|}{ Cultivation cycles (Year) } \\
\hline & \multicolumn{2}{|c|}{$1(2015)$} & \multicolumn{2}{|c|}{$2(2016)$} \\
\hline & (SCP) & $\mathrm{RSCP} \%$ & (SCP) & RSCP \% \\
\hline 1 & $17.86 \mathrm{a}$ & - & $18.54 \mathrm{a}$ & - \\
\hline 2 & $16.48 \mathrm{a}$ & 7.73 & $18.08 \mathrm{a}$ & 2.48 \\
\hline 3 & $15.90 \mathrm{a}$ & 10.97 & $17.34 \mathrm{ab}$ & 6.47 \\
\hline 4 & $13.82 \mathrm{~b}$ & 22.62 & $16.42 \mathrm{~b}$ & 9.82 \\
\hline 5 & $12.51 \mathrm{~b}$ & 29.96 & $13.32 \mathrm{c}$ & 28.16 \\
\hline $\mathrm{CV} \%$ & 12.56 & & 9.41 & \\
\hline
\end{tabular}

Note. The averages followed by the same lowercase letter in the column do not differ from each other by the Tukey test applied at the $5 \%$ probability level; CV: coefficient of variation.

The reduction in the starch content of the manioc roots estimated by the hydrostatic balance (SC) was confirmed by regression analyses between this factor and the scores attributed to M. fryanus larvae, with a linear and significant adjustment, indicating the starch content reduction for the first and second crop cycles, respectively (Figure 5).

For the evaluation of the starch content obtained by the extraction method with cassava processing (SCP\%), values of significant determination coefficients of 0.8939 and 0.8499 , respectively, were also observed for the first and second crop cyele, with better adjustment for the linear condition (Figure 6).

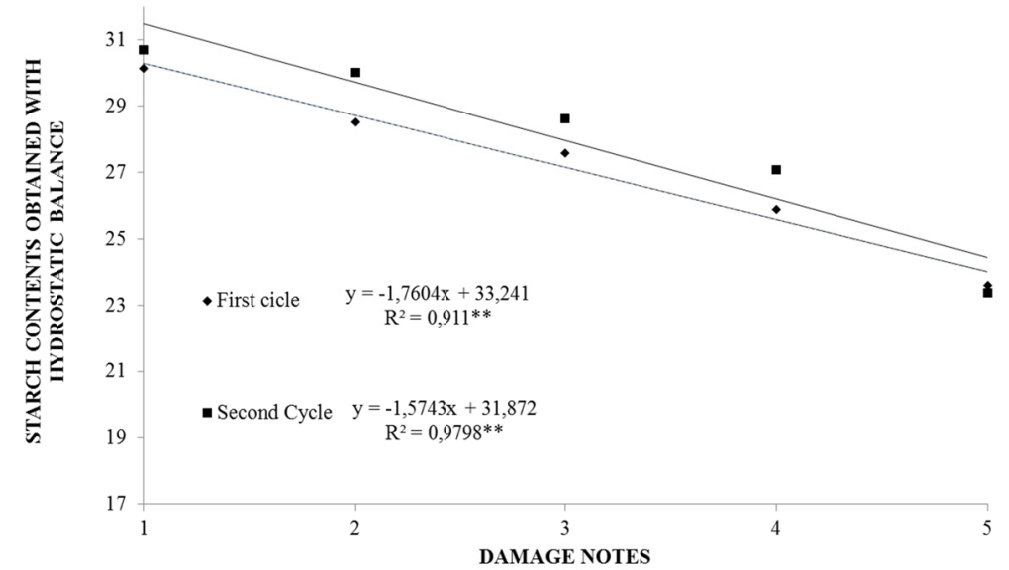

Figure 5. Effect of damage intensity of M. fryanus (Coleoptera: Vesperidae) larvae on the starch content of the IAC-90 variety in the first and second cropping cycles cropping cycles, estimated by the hydrostatic balance method, using samples with $3 \mathrm{~kg}$ of manioc. Umuarama, Paraná 2016 


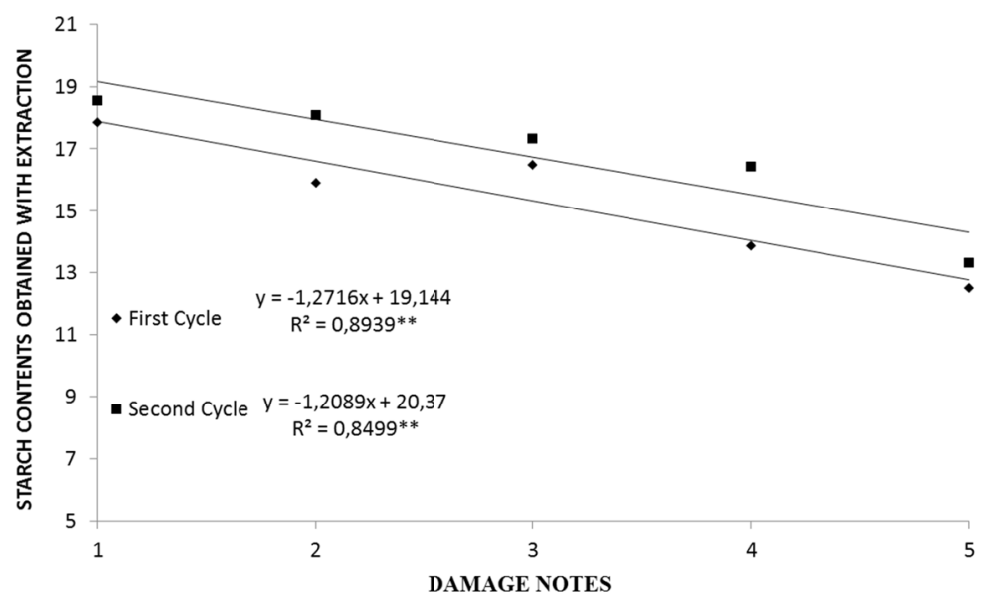

Figure 6. Effect of damage intensity of M. fryanus (Coleoptera: Vesperidae) larvae on the starch content of the IAC-90 variety in the first and second cropping cycles, obtained by the root processing method using samples of $1 \mathrm{~kg}$ of processed cassava. Umuarama, Paraná 2016

It is possible to affirm that the starch content estimated by the hydrostatic balance method (which determines the specific mass) and the extraction by processing of cassava, could show a decrease in cassava starch production when submitted to the stress caused by $M$. fryanus larvae. In addition, a complete relationship between the increase in the level of damage and the decrease of this evaluated factor has been observed.

\section{Discussion}

The damages caused by larvae of $M$. fryanus in cassava roots observed in the present study are expressive and provide a decrease in the productive values of this crop. It was possible to observe the beetle feeding on the roots and completely damage them, in all evaluations, in places where the sugar cane crop was previously cultivated. The complex of insects that occur in cassava and that live part of their life in the soil, particularly the Scarabaeidae and Vesperidae families, have increased their importance as agents causing primary damage in the tuberous roots. The record of $M$. fryanus damage in cassava is recent, and the actual damage caused by this pest in the roots and its effect on other parts of the plants until the present time is little known, as noted by Pietrowski et al. (2010) and Bellotti et al. (1999).

It is important to note that the M. fryanus species is considered a polyphagous pest, and the polyphagia characteristic observed for this insect can be explained by the presence of proteins from the cysteine and serine peptidase group present in the digestive tract, which leads to a more diverse feeding behavior (Nakayama et al., 2017).

However, the highest occurrence of M. fryanus in cassava crops in the northwest of the State of Paraná, is related to the planting sites that previously adopted crops considered preferential to this pest, such as sugarcane and the use of pasturage (Machado \& Habib, 2006).

Migdolus fryanus has a habit of living underground, and root damage is due to larval feeding. In the same plant there may be gradations of different root damage, and the more severe damage represented by perforations and the presence of microorganisms may result in a considerable drop in productivity. Similar damages were observed for crops such as sugarcane, pasturage, and pine (Wilcken et al., 2015; Machado et al., 2006b; Machado \& Habib, 2006).

The observation of the symptoms of damage in different roots, in the same plant, and with different degrees of severity can be explained by the habit of feeding and walking of the larvae in the soil, which at this stage of the life of the insect occurs both vertically and horizontally. It is dependent on climatic factors characterizing the higher feeding periods in dry seasons of the year, periods coinciding with the presence of more advanced instars near the cassava plants (Machado et al., 2006a; Machado \& Habib, 2006).

The behavior of this pest can be explained by the presence in the fatty tissues of the protein larvae of the Otopetrins group, which present a sensorial function in these more advanced insects, which are present near the cassava plants (Nakayama et al., 2017). Thus the management of $M$. fryanus depends on the knowledge of the behavior of all stages of life of the insect, and its relationship with the cultivated plants (Bento et al., 1992; Bento et al., 1993). 
The starch content estimated by the hydrostatic balance method and that obtained by the cassava processing method in roots that did not present with M. fryanus damage, under the conditions of this study, are within the recommended values for industrial use (Oliveira et al., 2011). However, from the moment of occurrence of symptoms of $M$. fryanus damage in the roots, the decrease in starch content was verified.

Besides water, starch is the most abundant constituent of cassava roots, and its decrease due to damage caused by M. fryanus, is because of root rot (Herren, 1994). The greatest drop in the productive parameters, such as starch content, can be caused by the formation of galleries and consequent soil deposition and onset of rot caused by opportunistic microorganisms and M. fryanus larvae, which penetrate into the roots and begin their colonization. This causes the most severe damage, such as rotting, and consequent fall in productive factors as noted for cassava and sugarcane (Machado et al., 2006a; Bellotti et al., 2012).

The decrease in starch content evaluated in cassava plants as a function of $M$. fryanus damage was less pronounced in roots that did not suffer severe damage (damage scores 2 and 3), indicating possible recovery of plants in the conditions of the second crop cycle, even with a longer period in contact with the soil conditions, which could lead to greater plant exposure to the larvae of the beetle and the occurrence of opportunistic microorganisms that penetrate the lesions caused by the larvae of M. fryanus, according to Camargo (2009).

\section{Conclusions}

The proposed notes on the scale of damage, allowed for estimating the losses caused by M. fryanus, in relation to starch in cassava. Notes four and five were related to the largest falls in starch content. Larger damages by $M$. fryanus larvae were verified under the conditions of the first crop cycle.

The decrease in terms of the amount of starch produced may lead to intensified losses to suppliers and the industry.

\section{Acknowledgements}

To the Brazilian agency "Coordenação de Aperfeiçoamento de Pessoal de Nível Superior (CAPES)" for financial support. The authors express sincere thanks to Dr. José Mauricio Simões Bento and your team (Laboratório de Ecologia Química e Comportamento de Insetos/Departamento de Entomologia e Acarologia-Universidade de São Paulo) for the identification of specie M. fryanus.

\section{References}

Barbosa, J. C., \& Maldonado Jr., W. (2015). Experimentação Agronômica \& AgroEstat: Sistema para análises estatísticas de ensaios agronômicos. Jaboticabal: Gráfica Multipress Ltda.

Bellotti, A. C., Campo, H. V. P., \& Hyman, G. (2012). Cassava production and pest management: Present and potential threats in a changing environment. Tropical Plant Biology, 5(1), 39-72. https://doi.org/10.1007/ s12042-011-9091-4

Bellotti, A. C., Smith, L., \& Lapointe, S. L. (1999). Recent advances in cassava pest management. Annual Review of Entomology, 44, 343-370. https://doi.org/10.1146/annurev.ento.44.1.343

Bento, J. M. S., Albino, F. E., Della Lucia, T. M. C., \& Vilela, E. F. (1992). Field trapping of Migdolus fryanus Westood (Coleoptera: Cerambycidae) using natural sex pheromone. Journal Chemical Ecology, 18(2), 245-251. https://doi.org/10.1007/BF00993756

Bento, J. M. S., Della Lucia, T. M. C., \& Frighettor, T. S. (1993). Male response to natural sex pheromone of Migdolus fryanus Westwood (Coleoptera: Cerambycidae) females as affected by daily climatic factors. Journal of Chemical Ecology, 19(10), 2347-2351. https://doi.org/10.1007/BF00979669

Camargo, M. T. L. A. (2009). Estudo etnobotânico da mandioca (Manihot esculenta Crantz-Euphorbiaceae), na diáspora africana. Salvador: Fundação Gilberto Freyre.

FAO (Food and Agriculture Organization of the United Nations). (2008). Why Cassava? Roma, Itália. Retrieved from http://www.fao.org/ag/agp/agpc/gcds/index_en.html

Herren, H. R. (1994). Cassava pest and disease management: An overview. African Crop Science Journal, 2(4), 345-353.

Juste Junior, E. S. G., Carvalho, V. D., Vilela, E. R., Clemente, P. R., Corréa, H., \& Moraes, A. R. (1983). Comparação entre o método físico da balança hidrostática e métodos químicos na determinação do amido em raízes de mandioca. Pesquisa Agropecuária Brasileira, 18(1), 55-57. 
Machado, L. A., \& Habib, M. (2006). Migdolus fryanus (Westwood, 1863) (Coleoptera: Vesperidae): Praga da cultura da cana-de-açúcar. Arquivos Instituto Biológico, 73(3), 375-381.

Machado, L. A., Habib, M., Leite, L. G., \& Carregari, L. C. (2006). Aspectos biológicos e morfológicos de Migdolus fryanus (Westwood, 1863) (Coleoptera: Vesperidae). Arquivos Instituto Biológico, 73(4), 447-454.

Machado, L. A., Habib, M., Leite, L. G., \& Mendes, J. M. (2006). Estudos ecológicos e comportamentais de Migdolus fryanus (Westwood, 1863) (Coleoptera: Vesperidae), em cultura de cana-de-açúcar, em quatro municípios do estado de São Paulo. Arquivos Instituto Biológico, 73(4), 227-233.

Maeda, M., \& Dip, T. M. (2000). Curvas de porcentagem mássica de água versus peso específico em vegetais in natura-otimização de processos industriais pela seleção via teste da matéria-prima. Food Science and Technology, 20(3), 309-313. https://doi.org/10.1590/S0101-20612000000300006

Nakayama, D. G., Santos Junior, C. D., Kishi, L. T., Pedezzi, R., Santiago, A. C., Soares-Costa, A., \& Silva, F. H. (2017). A transcriptomic survey of Migdolus fryanus (sugarcane rhizome borer) larvae. PLoS ONE, 12(3), 1-23. https://doi.org/10.1371/journal.pone.0173059

Oliveira, N. T., Alves, J. M. A., Uchôa, S. C. P., Rodrigues, G. S., Melville, C. C., \& Albuquerque, J. A. A. (2011). Caracterização e identificação de clones de mandioca produzidos em Roraima para o consumo in natura.RevistaAgro@mbiente On-line, 5(3),188-193. https://doi.org/10.18227/1982-8470ragro.v5i3.624

Pietrowski, V., Ringenberger, R., Rheinheimer, A. R., Bellon, P. P., Gazola, D., \& Miranda, A. M. (2010) Insetos-Praga da cultura da mandioca na região Centro-Sul do Brasil. Marechal Cândido Rondon: UNIOESTE/EMBRAPA.

Sagrilo, E., Vidigal Filho, P. S., Pequeno, M. G., Vidigal, M. C. G., Scapim, C. A., Kvitschal, M. V., ... Rimoldi, F. (2006). Effect of harvest period on foliage production and dry matter distribution in five cassava cultivars during the second plant cycle. Brazilian Archives of Biology and Technology, 49, 1007-1018. https://doi.org/10.1590/S1516-89132006000700019

Ugwu, J. A., \& Ojo, M. O. (2015). Diversity and abundance of insects in mulberry ecosystem in Ibadan South Western Nigeria. Research Journal of Forestry, 9(2), 58-64. https://doi.org/10.3923/rjf.2015.58.64

Wilcken, C. F., Orlato, C., \& Ottati A. L. T. (2005). Ocorrência de Migdolus fryanus (Coleoptera: Cerambycidae) em plantios de Pinus caribaea var. hondurensis. Revista Árvore, 29(1), 171-173. https://doi.org/10.1590/ S0100-67622005000100018

\section{Copyrights}

Copyright for this article is retained by the author(s), with first publication rights granted to the journal.

This is an open-access article distributed under the terms and conditions of the Creative Commons Attribution license (http://creativecommons.org/licenses/by/4.0/). 